\title{
FOREST COVER DYNAMICS IN THE CITY OF POZNAŃ FROM 1830 TO 2004
}

\author{
Andrzej Macias, Marta Dryjer \\ Adam Mickiewicz University, Institute of Physical Geography and Environmental Planning, Poznań, Poland
}

Manuscript received July 15, 2010

Revised version August 26, 2010

Macias A. \& Dryjer M., 2010. Forest cover dynamics in the city of Poznań from 1830 to 2004. Quaestiones Geographicae 29(3), Poznań 2010, Poznań 2010, pp. 47-57, 9 Figs, 3 Tabs. ISBN 978-83-62662-04-3. ISSN 0137-477X. DOI: 10.2478/v10117-010-0022-5.

ABSTRACT. Forests on the urban areas are of a great importance for the biodiversity of this territory. Moreover, they play numerous functions in the environment and constitute, at present, on important element of the ecological urban system. Nevertheless, the changes of the forest areas in the city of Poznań have never been discussed so far. This article presents the results of research of the changes of forest areas in Poznań within the administrative borders of Poznań in 2004. It was performed for the period 1830-2004 for six selected moments in which topographic maps of this area were prepared i.e. 1830, 1888, 1940, 1960, 1979 and 2004 During this period forest area increased by $2367 \mathrm{ha}$. The effect of numerous afforestations and deforestations is that forest area which was not subject to these treatments from 1830 to 2004 constitutes only 481 ha (14.6\% of forest areas of Poznań). Four periods of dynamics of changes of forest areas were distinguished. During the last one, taking place presently, forest area has decreased slightly. In the case of Poznań, maintaining forests is significant from the point of view of their importance not only for functioning of green wedges but also the whole environment of this city. Therefore, one of the directions of spatial development of the city of Poznan should be maintaining and increasing forest areas as the element of the implementation of sustainable development principles.

KEYWORDS: forest, changes of forest areas, land use, Poznań, Poland

Andrzej Macias, Marta Dryjer, Department of Integrated Geography, Institute of Physical Geography and Environmental Planning, Adam Mickiewicz University, Dzięgielowa 27, 61-680 Poznań, Poland, e-mail: macias@amu.edu.pl,

martadryjer@02.pl

\section{Introduction}

Changes of forest areas are one of the most often examined forms of contemporary area cover dynamics occurring as a result of human activity (Kozak 2005, Barbier, Burgess \& Grainger 2010). Forests on the urban areas are of a great importance for the biodiversity of this territory. Moreover, they play numerous functions in the envi- ronment and constitute, at present, an important element of the ecological urban system (see Grey 1996, Miller 2007, Moll \& Ebenreck 1989, Oleksiejuk \& Jankowska 2007)The issue of changes of forest areas in Wielkopolska region has already been touched upon in literature but most often the research comprised bigger area, namely the district of Poznan or the whole region. 
Table 1. The process of shrinking of forest and swamp areas in Poznań district acc. to Hładyłowicz (1932)

\begin{tabular}{|c|c|c|c|c|c|c|c|c|}
\hline \multirow{4}{*}{$\begin{array}{l}\text { Poznań district } \\
\left(\text { area } 8,780 \mathrm{~km}^{2}\right)\end{array}$} & \multicolumn{2}{|c|}{$\begin{array}{l}14^{\text {th }} \text { century } \\
(1370-1400)\end{array}$} & \multicolumn{2}{|c|}{$\begin{array}{l}1^{\text {th }} \text { century } \\
(1580-1600)\end{array}$} & \multicolumn{2}{|c|}{$\begin{array}{l}18^{\text {th }} \text { century } \\
(1780-1800)\end{array}$} & \multicolumn{2}{|c|}{$20^{\text {th }}$ century } \\
\hline & \multicolumn{8}{|c|}{ Forest and swamp area } \\
\hline & $\mathrm{km}^{2}$ & $\%$ & $\mathrm{~km}^{2}$ & $\%$ & $\mathrm{~km}^{2}$ & $\%$ & $\mathrm{~km}^{2}$ & $\%$ \\
\hline & 5,608 & 57.7 & 4,386 & 49.9 & 3,391 & 38.6 & 2,907 & 33.1 \\
\hline
\end{tabular}

Historically the works of Hładyłowicz (1932) and Błaszyk (1974) play an important role. According to the former, not enough attention was paid to the investigation of changes which took place due to spreading of crop lands for centuries and therefore decreasing forest and swamp area. The district of Poznań created in the $14^{\text {th }}$ century a sharp contrast between forested and desolate areas in western and northern part and densely inhabited and forest-free areas in middle and south-east part. The surroundings of Poznań and Kiekrz (location of Poznan, Kiekrz and all other place-names used in the text, should appear on an additional map on Fig. 2) were very densely inhabited (Hładyłowicz 1932). On the right bank of the river Warta, to the east and south from Poznań, forest-free fields and meadows spread to Kostrzyn and Środa, thus the names of settlements such as Kobylepole ("pole" in Polish "field"), Karspole and Starołęka ("Łęka"="łąka" in Polish "meadow"). Larger forest areas lay near Głuszyna, Swarzędz and Kostrzyn, and mostly in northern part on sandy soils around Murowana Goślina, Zadzim and Rogoźno (Hładyłowicz 1932). The changes of forest areas and swamp areas connected with them within this district over centuries are presented in the Table 1 and Fig. 1.

The decrease in forest and swamp areas (see Table 1) was caused by the fact that Wielkopolska has been the region with high and constantly growing population for a long time, and this is why settlements and agriculture has been developing there for centuries. Until mid $19^{\text {th }}$ century

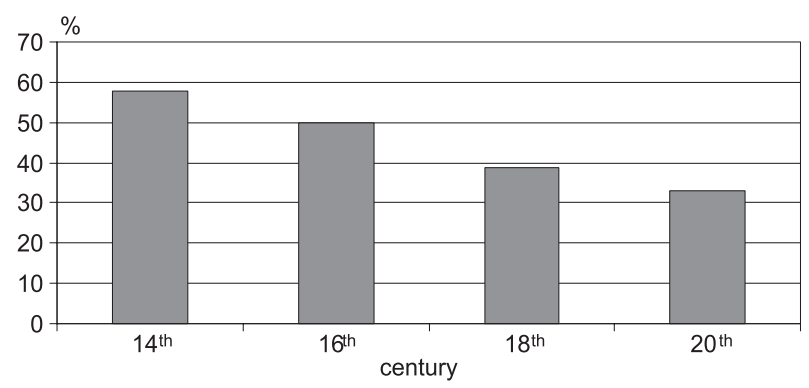

Fig. 1. Forest and swamp area cover proportion in Poznań district beetwen $14^{\text {th }}$ and $20^{\text {th }}$ century. the share of forests and swamps dropped to approx. $28 \%$ so it decreased by half in relation to the end of $14^{\text {th }}$ century. Thus at the end of $14^{\text {th }}$ century, when recorded occupancy of forest for the benefit of settlements started, forest cover proportion of Wielkopolska region was assessed to be slightly more than half of its total area. Historic research showed that in $15^{\text {th }}$ and $16^{\text {th }}$ century logging of forests was mostly the result of peasant economy. Intensified agricultural settlements, especially in the period from the $15^{\text {th }}$ century to the $18^{\text {th }}$ century caused the withdrawal of forests from the areas located near the river Warta valley. The settlement process accelerated in the $17^{\text {th }}$ and $18^{\text {th }}$ centuries (Błaszyk 1974).

At present the lack of reports concerning the issues of dynamics and formation of forests of the city of Poznan is noticeable. There are many theses devoted to the profile of urban greenery, however forest areas are not fully described in them. Only in the study entitled Środowisko naturalne miasta Poznania edited by Kurek (1996) an information on forests and their role in the formation of urban ecosystem is included. Therefore, the need arose to conduct a full-range analysis of the dynamics of the changes of forest areas of the city of Poznań.

The main objective of this article was to present spatial diversification of forest areas at the area comprised within current administrative borders of Poznań in the period 1830-2004. Furthermore, an effort was made to obtain the answer to the question of how large forest area remained unchanged within this period and what was the growth and loss of forest area within this time period.

\section{Study area, data and methods}

In 2004 the area of the city of Poznan comprised the area of 26137 ha (currently 26185 ha data from Regional Data Bank 2009), which placed Poznań at the $6^{\text {th }}$ position among Polish cities with respect to their area (behind Warszawa, 
Table 2. Comparison of the area of biggest Polish cities, including the area of forests and forest cover proportion for 2008 acc. to Regional Data Bank (2009)

\begin{tabular}{|c|c|c|c|}
\hline City & Area (ha) & $\begin{array}{c}\text { Forest area } \\
\text { (ha) }\end{array}$ & $\begin{array}{c}\text { Forest cover } \\
\text { proportion }\end{array}$ \\
\hline Warszawa & 51,724 & $8,118.1$ & 15.70 \\
\hline Kraków & 32,680 & $1,506.2$ & 4.61 \\
\hline Łódź & 29,325 & $2,865.9$ & 9.77 \\
\hline Wrocław & 29,282 & $2,162.2$ & 7.38 \\
\hline Poznań & 26,185 & $4,089.4$ & 15.62 \\
\hline Gdańsk & 26,162 & $4,688.9$ & 17.92 \\
\hline
\end{tabular}

Łódź, Kraków, Wrocław and Gdańsk). The administrative boundaries of the city of Poznan were defined on the basis of a topographical map of 2004 (Head Office of Geodesy and Cartography, 2005). Population amounted to 556,442 people (status as at the end of March 2009), the city was placed at $5^{\text {th }}$ position among Polish cities (behind Warszawa, Kraków, Łódź and Wrocław). With respect to forest cover proportion, Poznan is on the third place among Polish cities, being only slightly behind Gdańsk and Warszawa, the capital city of Poland (see Table 2).

Poznań has been growing gradually over the centuries, adjoining neighbouring areas and towns. Spatial development of the city over the last 115 years is depicted in Fig. 2 and Fig. 3. Forest areas in the studied period, within the limits of current administrative boundaries, were subject to frequent changes as well (see Fig. 4).

What we understand under the term "forest" is a significant issue. There are many definitions of this term in literature (e.g. Obmiński 1978, Mierzwiński 1991, Kocięcki \& Andrzejewski 1991, Global Forest Resource 2000). For the needs of this article, an operative definition, being the modification of the meaning included in the Act on forests of September $28^{\text {th }}, 1991$ (Journal of Laws of 1991, No 101, Item 444), was accepted. It is as follows: forest area overgrown with woody plants, not smaller than 0.1 ha, comprising tree stands at which forest economy is run.

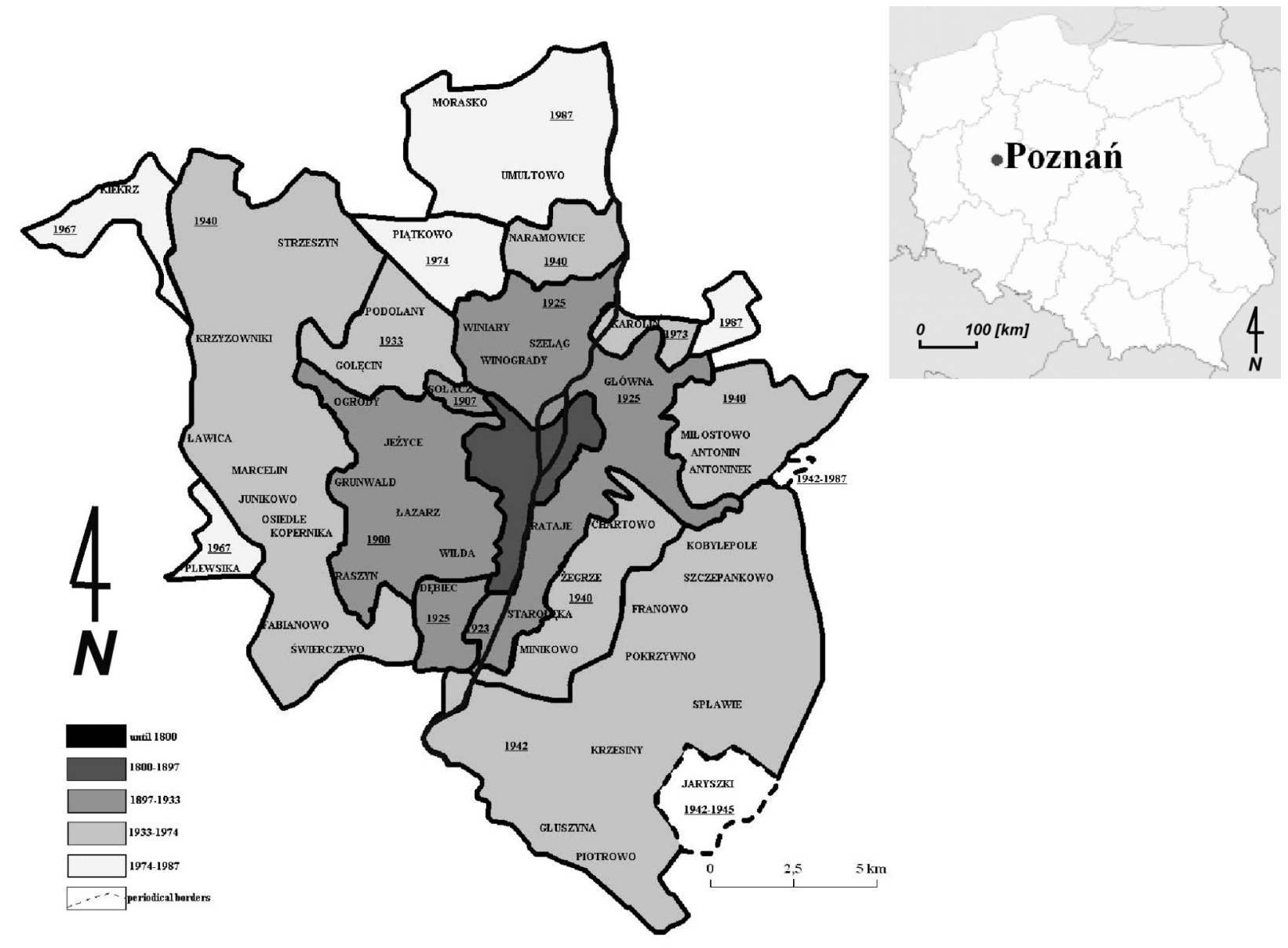

Fig. 2. Changes of administrative borders of Poznań (Matuszyńska 2001). 


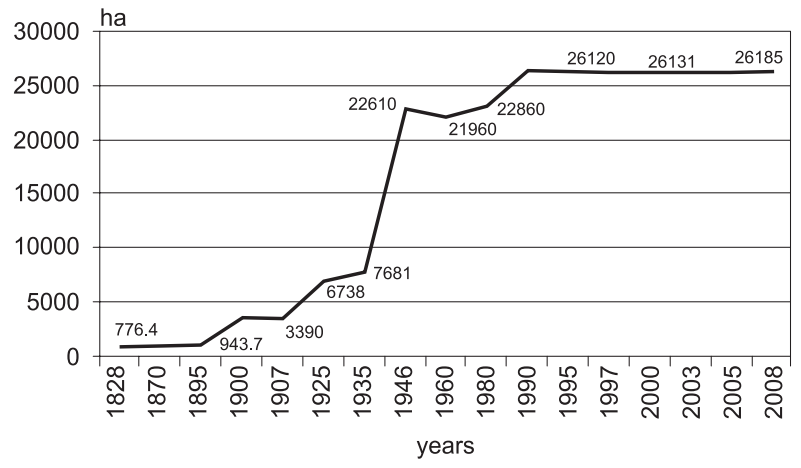

Fig. 3. Area of the city of Poznań between 1828 and 2008.

The total forest land in Poznań comprise officially 4003.7 ha (data from 2004 - Regional Data Bank 2009), out of which: 2580.0 ha constitute municipal forests, 1124.7 ha constitute state forests, 295.0 ha - private forests and 4 ha constitute public forest areas of the State Treasury belonging to public institutions of the city of Poznan. The forests of Poznań can be divided into three basic kinds with respect to protection: protected forests $(0.01 \%)$, protective forests ${ }^{1}(92.99 \%)$ and cultivated forests $(7.0 \%)$. From other sources it is known that forest areas comprise only 3505.1 ha (Rocznik Statystyczny Poznania, 2005). Next, forest area according to Wojewódzki Ośrodek Dokumentacji Geodezyjnej i Kartograficznej w Poznaniu (Regional Centre for Geodetic and Cartographic Documentation in Poznań) was equal 3497.0 ha (unpublished data).

As the main objective of this article is to define spatial and time-related dynamics of changes of using forest areas at the area of the city of Poznan, the main source of data were topographic maps, mostly in scale 1:25,000. Source materials were as follows:

- topographic map, the so-called Urmesstischblatt of 1830 (Preussischer Generalstab, without year of realization),

- topographic map Messtischblatt of 1888 (Preussischen Landeaufnahme, 1890),

- topographic map Messtischblatt of 1940 (Reichsamt fuer Landesaufnahme, 1944),

1 Protective forests - there are the forests of a limited, economic exploitation, performing additionally functions connected with protection of soils, waters, landscapes or areas inhabited by people. They were created on the basis of Act on forests of 28th September 1991 (Journal of Laws of 1991, No 101, Item 444).

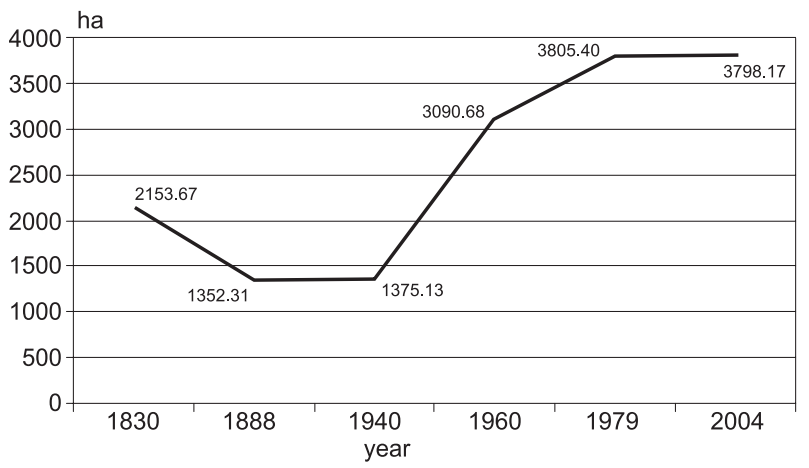

Fig. 4. Dynamics of changes of forest areas at the area of the city of Poznan from 1830 to the present day within administrative boundaries of 2004 .

- topographic map of districts of Poland of 1960 (Topographic Authority of the General Staff of the Polish Army, 1963),

- topographic map of Poland in layout "1965" of 1979 (National Enterprise of Geodesy and Cartography, 1980),

- topographic map of Poland of 2004 (Head Office of Geodesy and Cartography, 2005).

Due to the assumption made in this article that the research area is the area of the city of Poznan within administrative borders in 2004, as well as due to their frequent changes (see Table 1 and Fig. 3), historic statistical data comprising forest areas (among others statistics run for the needs of Prussia authorities - see e.g. Gemeindelexikon 1888) could not have been used.

Topographic maps named Urmesstischblatt (Preussischer Generalstab) caused many problems before they could be analysed owing to the fact that they were not cartometric. Information on forest areas was transferred from this map into a contemporary topographic layout. Characteristic points and facilities which have not changed their location so far were used for this operation. Spatial references were made in the layout of 1965 (zone 4) based on topographic map in the scale 1:25,000. Geometric transformation to abovementioned layout of coordinates was made with MapInfo programme, with the use of the $2^{\text {nd }}$ order polynomial model of geometric transformation. The error of location of geometric transformation points fluctuated from 4 to 5 pixels. Such difficulties did not occur with reference to other maps, and spatial data concerning forest area was also transferred to the mentioned topographic layout, which was the same for all analyzed periods. 
Table 3. Separation of forest areas at analyzed topographic maps

\begin{tabular}{|c|c|c|}
\hline Kind of topographic map & Original nomenclature & Equivalent in English \\
\hline \multirow{3}{*}{ Urmesstischblatt } & Wald (Stangenholz) & Forest \\
& Junges Holz & Young stand \\
& Laub Holz & Deciduous forest \\
& Nadel Holz & Foniferous forest \\
\hline \multirow{3}{*}{ Messtischblatt } & Wald & Forest \\
& Laubwald & Deciduous forest \\
& Nadelwald & Coniferous forest \\
& Mischwald & Mixed forest \\
\hline \multirow{2}{*}{ Topographic map of Poland } & Las wysokopienny & High forest \\
& Las liściasty & Deciduous forest \\
& Las iglasty & Coniferous forest \\
& Las rzadki & Thin forest \\
\hline
\end{tabular}

This aimed at decreasing measurement error. All cartographic research was made by means of the MapInfo Professional ver. 9.0 programme (Pitney Bowes Software Inc. 2007).

Forest areas were interpreted from the maps according to map classification schemes (see Table 3). Research on the analyzed maps included all forest areas, irrespective of age (see Urmesstischblatt - Junges Holz) and stand density (see Topographic map of Poland - Las rzadki).

Having prepared the maps presenting forest areas in Poznan, the next stage involved the measurement of their area. This was done with the use of aforementioned programme MapInfo Professional ver. 9.0. It constituted the basis for the calculations of percentage share of forest areas in general area of the city of Poznan in particular periods, defining tendencies of their conversions, showing areas of forest which has not changed, and then deforested and re-forested areas. This research was supplemented with information obtained from the following forest arrangement plans: municipal of the city of Poznan (Plan Urzadzenia Lasu Komunalnego 2002), Forest Division Babki (Plan Urządzenia Lasu Nadleśnictwa Babki 2008), Forest Division Konstantynowo (Plan Urządzenia Lasu Nadleśnictwa Konstantynowo 2008), Forest Division Łopuchówko (Plan Urzadzenia Lasu Nadleśnictwa Łopuchówko 2008) and private persons' forests.

On the basis of the above-mentioned elaborations, it has been stated that in the city of Poznan the majority constitute coniferous and mixed forests. Among the types of forest habitats dominate fresh forest habitats (mainly fresh mixed broadleaved forest, fresh mixed coniferous for- est, fresh broadleaved forest and fresh coniferous forest), they cover $87 \%$ of the forest area. Swamp and flooded forest habitats (flooded broadleaved forest, alder swamp forest and ash-alder swamp forest) cover $8 \%$ and moist forest habitats (moist broadleaved forest, moist mixed coniferous forest, moist mixed broadleaved forest) $5 \%$ of the forest area. The main forest formative species is pine $(57.7 \%)$. Among the remaining species, worth mentioning are: birch and hornbeam - 16.3\%, oak, maple, elm, ash and sycamore $-14.5 \%$, lime, willow, poplar and aspen $-7.4 \%$ as well as alder $-3.6 \%$. The remaining species have marginal contribution. The recreation of habitat and species structure of the forests of the Poznan city in the previous periods requires further research and don't constitutes the aim of this work.

\section{Results and discussion}

Over two centuries, forest areas of the city of Poznań demonstrated great dynamics of changes as an element of adjusting to social and economic conditions of the city (see Fig. 5a and 5b). The $19^{\text {th }}$ century was characterized by decrease in forest areas from 2154 ha in 1830 to 1352 ha in 1888 (decrease by $37.21 \%$ ) (see Fig. 4). Deforestation occurred at the areas of Morasko and Naramowice, Kobylepole and Dębina. Whereas in 1888 larger forest areas were located at the area of Dębiński Forest, Kobylepole, Malta, Zieleniec, Morasko and Golęcin.

Forest areas in 1940 comprised 1375 ha within current administrative borders of Poznan. Significant increase in forest areas in relation to the 


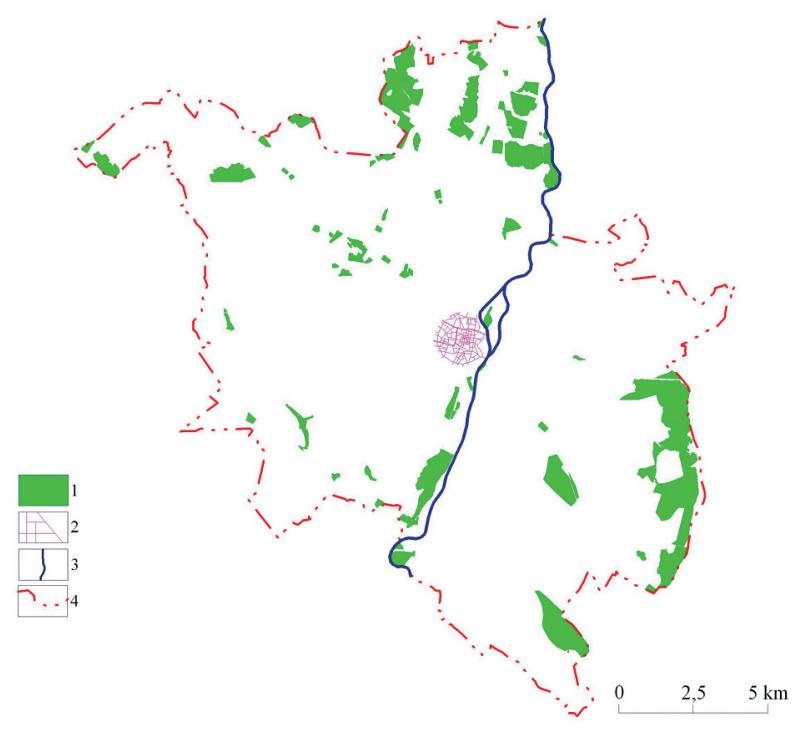

Fig. 5a. Forest areas in the area of city Poznań in 1830 within the administrative boundaries of 2004.

1 - forests, 2 - city center, 3 - Warta river, 4 - border of Poznań

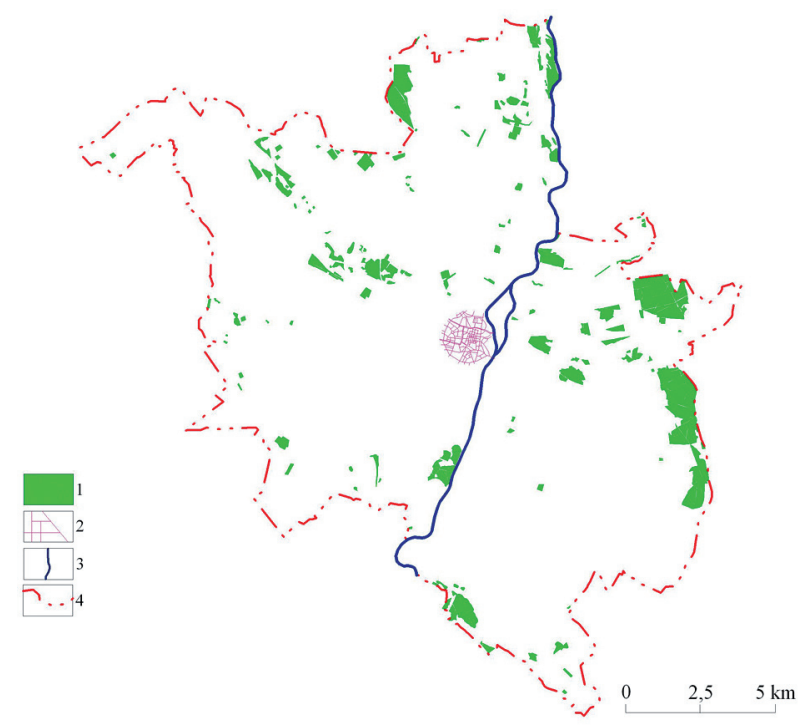

Fig. 5c. Forest areas in the area of city Poznan in 1940 within the administrative boundaries of 2004 .

previous period did not take place. Bigger changes occurred in 1924 when municipal authorities purchased the estate of Naramowice and forested its wastelands (see Fig. 5c).

Forest areas in 1960 already covered 3091 ha of the current area of the city (Fig. 4). In comparison to the previous period, a significant increase in forest areas took place because forest area increased by as much as $125 \%$ (over 1715 ha of forest growth). This took place during and shortly after World War II. At that time works consisting in artificial plantings of the areas of Dębiński For-

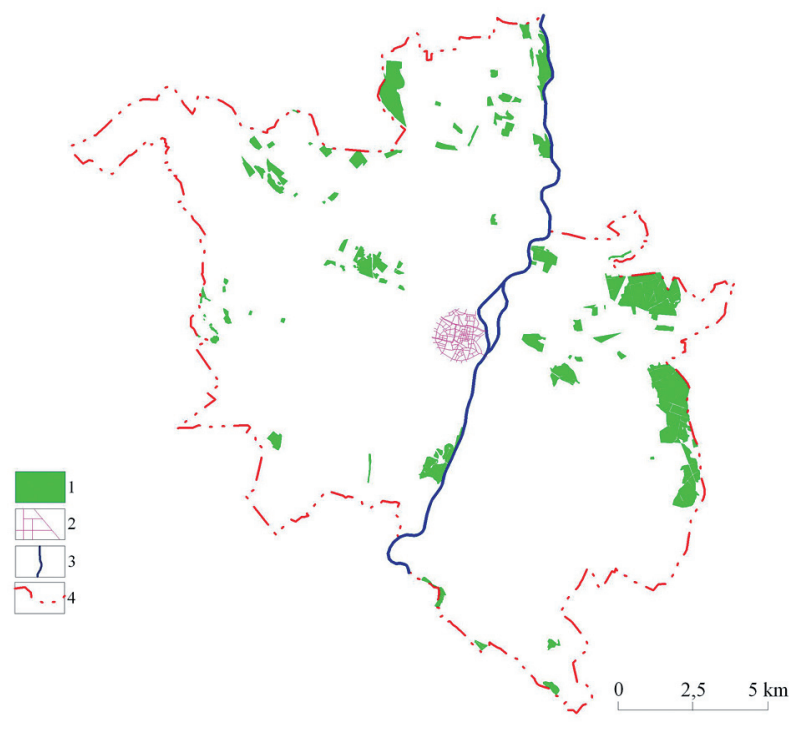

Fig. 5b. Forest areas in the area of city Poznań in 1888 within the administrative boundaries of 2004.

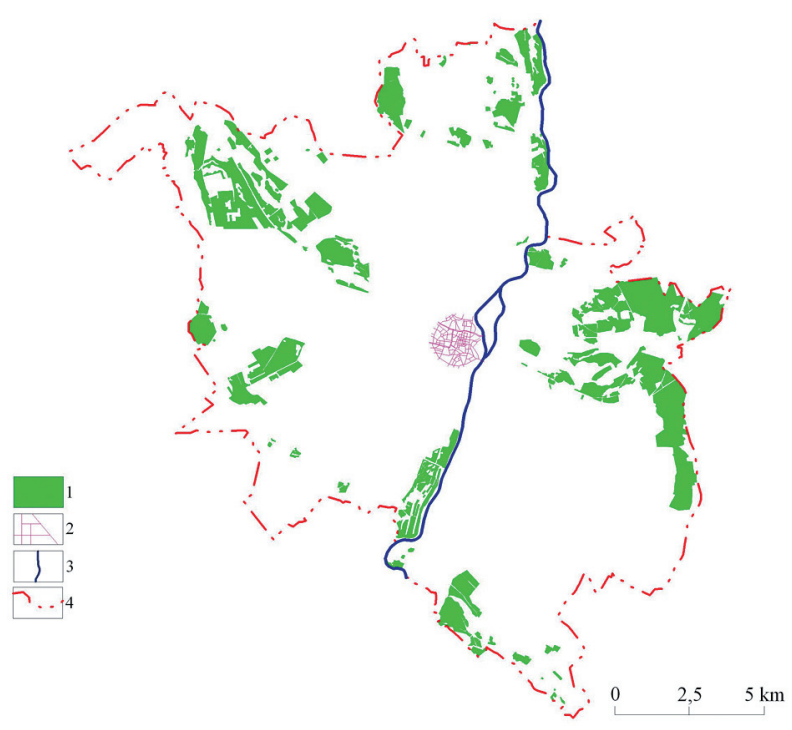

Fig. 5d. Forest areas in the area of city Poznań in 1960 within the administrative boundaries of 2004.

est, Głuszyna, Starołęka, Kobylepole, Główieniec was performed. Original and secondary succession of forest stands was of lesser importance. Artificial water reservoirs were created during 1943-1952: Malta and Rusałka, of which were newly planted trees formed the natural buffer zones. The areas of Radojewo, Morasko, Naramowice and Umultowo as well as Strzeszyńskie and Kierskie Lakes: Krzyżowniki, Strzeszyn and Psarskie were forested. Marceliński Forest came into existence in Junikowo district (see Fig. 5d). 


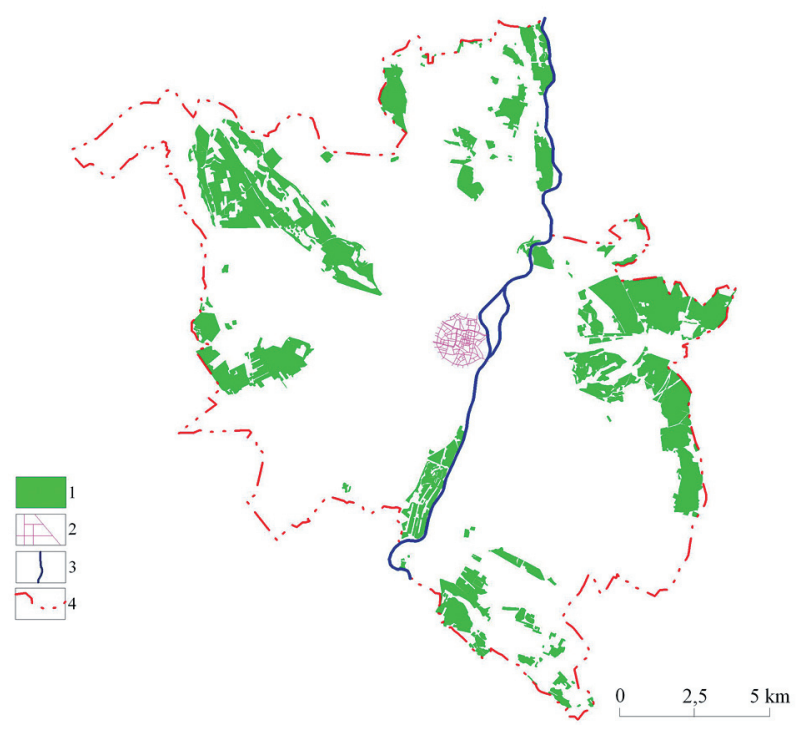

Fig. 5e. Forest areas in the area of city Poznań in 1979 within the administrative boundaries of 2004 .

The area of wooded areas in 1979 amounted to 3805 ha (Fig. 4). This was an the increase in forest areas by $23 \%$ in relation to the previous period. Artificial afforestation of the areas of Strzeszyńskie and Kierskie Lakes, Junikowo and Mareceliński Forest as well as the southern areas of the city: Starołęka, Głuszyna and Piotrowo was continued (see Fig. 5e).

Forested areas of the city of Poznan in 2004 comprised 3798 ha (Fig. 4), so at the beginning of the $21^{\text {st }}$ century a decreasing tendency of the area of forested areas was observed, the reasons for which was mostly road construction (see Fig. 5f).

During the analyzed period forest cover proportion of the city of Poznan varied. Taking into consideration the city territory of 2004 (26,137 ha), forest cover proportion reached the highest value in $1979-14.6 \%$ of the share in the total area of the city, and the smallest - at the end of $19^{\text {th }}$ century, at that time it amounted only to $5.2 \%$ of the total area of the city of Poznan (see Fig. 6). The growth of afforestation rate from 1352 ha in 1888 to 3091 ha in 1960 is the consequence of well conducted forestation works in 1940s and 1950s. The main aim of these works was planting of green wedges of the city of Poznan. Constant growth of forest areas in the analyzed area occurred in the second half of the $20^{\text {th }}$ century. Considering the development of urban agglomeration and growing human pressure maintenance of such a high share of forests of the total area of this city will require careful implementation of sustainable develop-

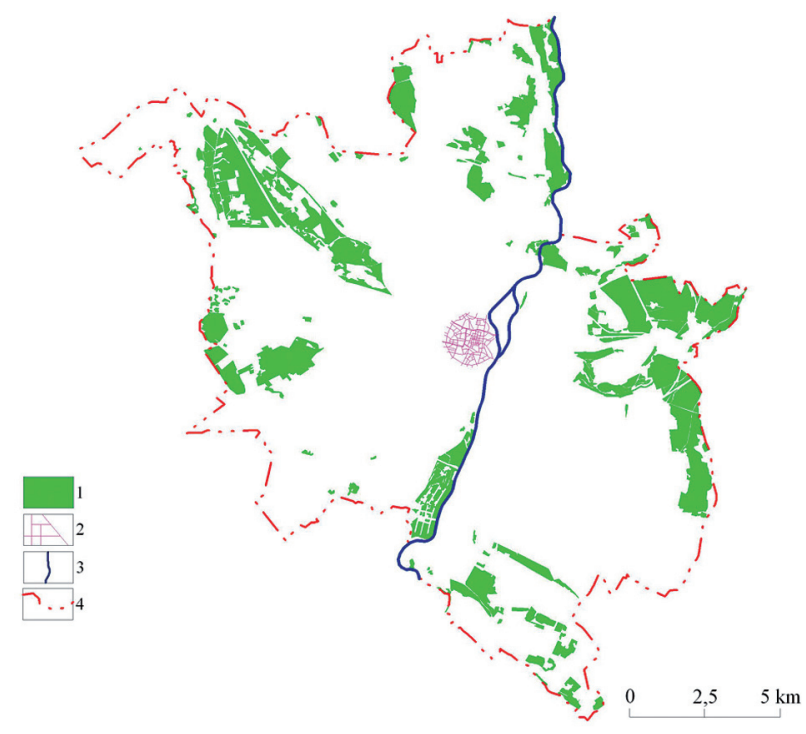

Fig. 5f. Forest areas in the area of city Poznań in 2004 within the administrative boundaries of 2004.

ment of forest areas and forestry. As already mentioned, within the last dozen or so years, not only a lack of increase in forest areas is noticeable but also their partial decrease. Forests constitute one of the most important elements of the city ecological system and serve a number of important functions in the environment. The most important factors influencing such conjuncture include allocating forest areas for economic projects and tree felling when upgrading roads.

The balance of forest area is an important element of the analysis. It consists of both unchanged forest areas (which were not subject to change within the analyzed period) and newly forested areas as well as deforestation areas (meaning converted into non-forest use). As, at the analyzed maps, forests were examined within permanent administrative boundaries of the city

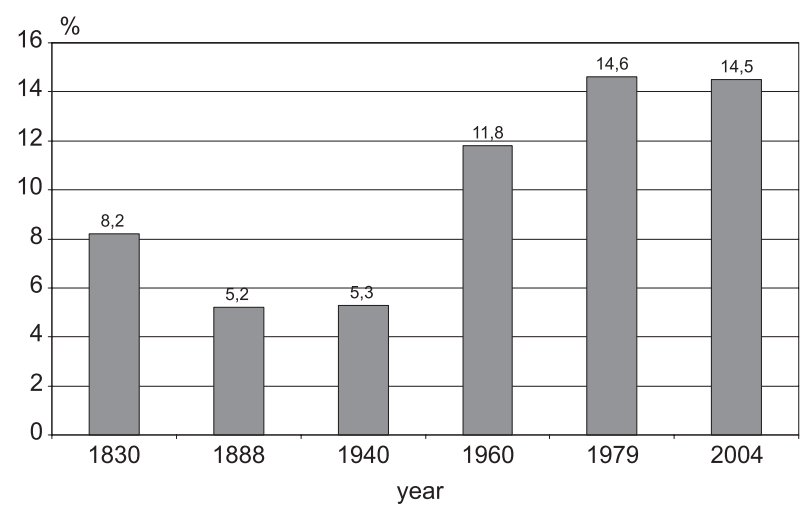

Fig. 6. Changes of the forest cover proportion in Poznań between 1830 and 2004 


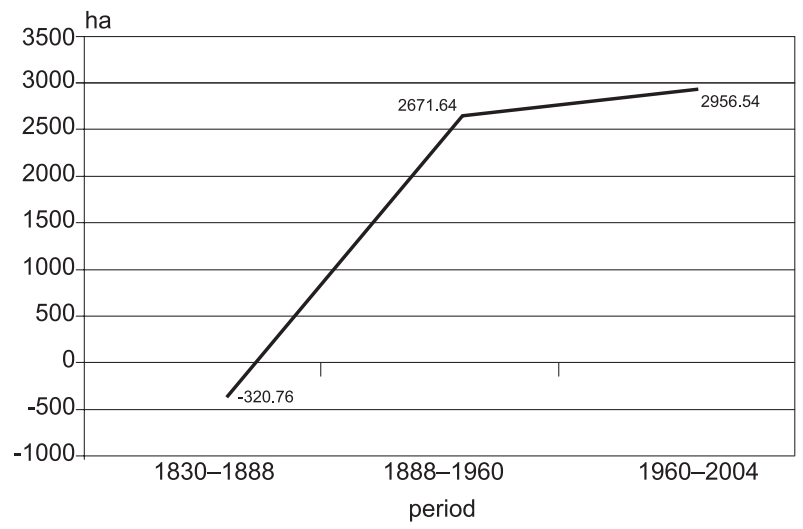

Fig. 7. Dynamics of the balance of forest areas of the city of Poznań between 1830 and 2004.

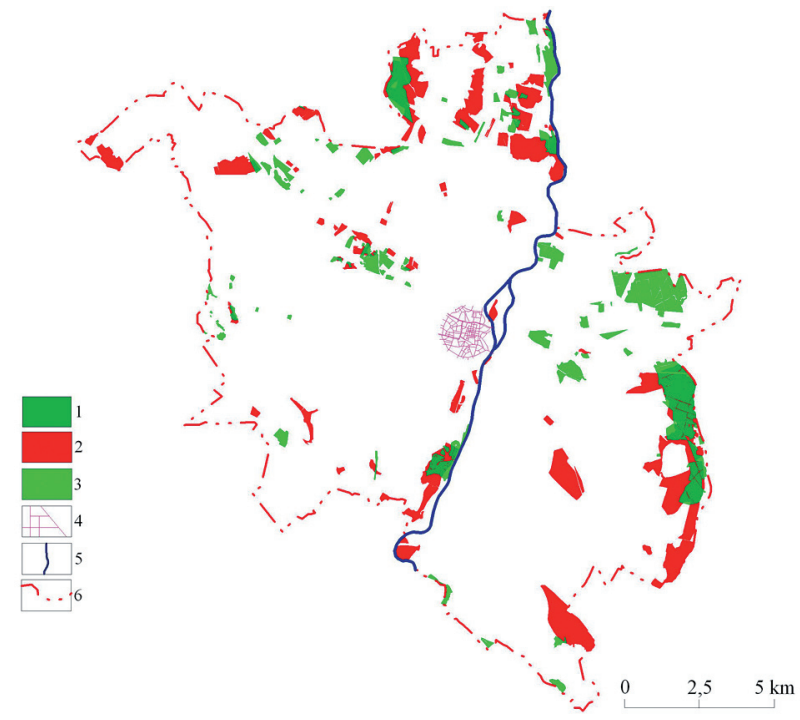

Fig. 9a. Changes of forest area of the city of Poznań between 1830 and 1888.

1 - forest without changes, 2 - deforestation, 3 - afforestation, 4 city center, 5 - Warta river, 6 - border of Poznań in 2004.

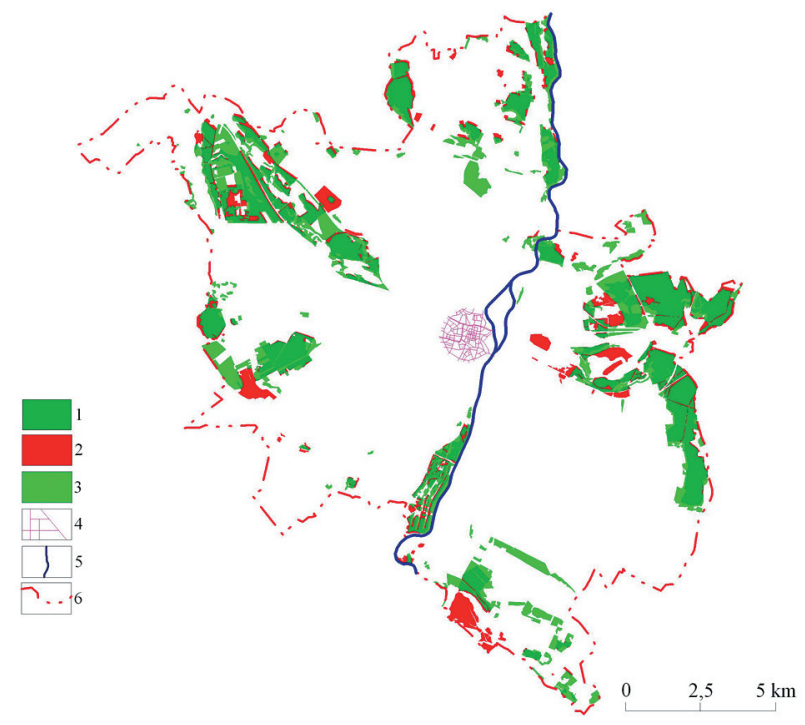

Fig. 9c. Changes of forest area of the city of Poznań between 1960 and 2004.

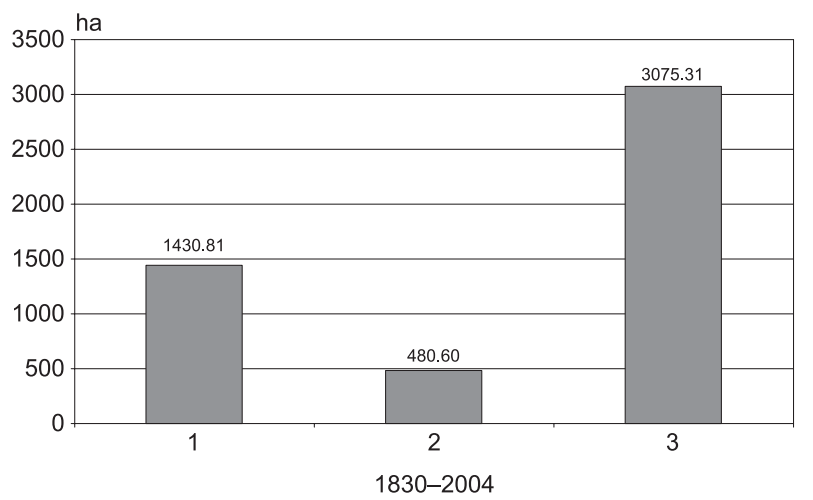

Fig. 8. Balance of forest areas of the city of Poznań between 1830 and 2004.

1 - deforestation, 2 - forests without changes, 3 - afforestation.

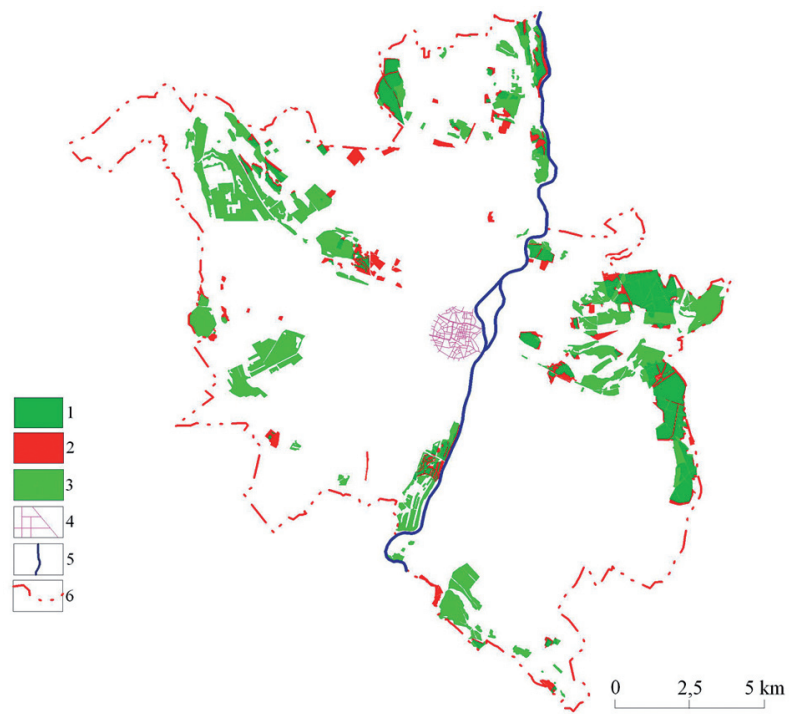

Fig. 9b. Changes of forest area of the city of Poznań between 1888 and 1960.

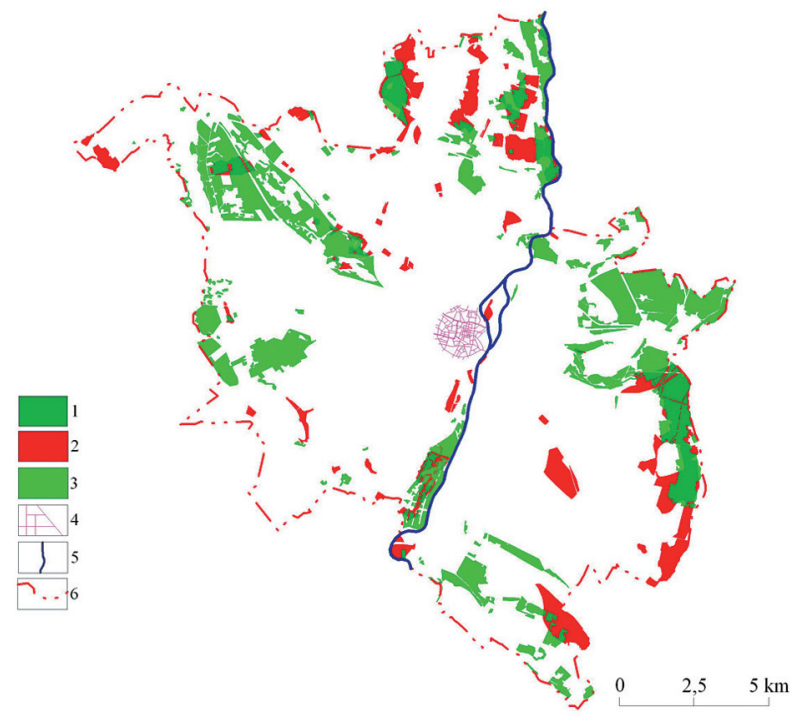

Fig. 9d. Changes of forest area of the city of Poznań between 1830 and 2004. 
of Poznań, remaining testing ground comprised insignificant and small parts of maps thus they were omitted (it was decided that they have no impact on the final result of the forest area). The balance of forest areas for the periods discussed is presented below.

In the first period 1830-1888 the dominant component of the forest balance was deforestation. Decrease in forest areas amounted to 1673 ha within this period. Unchanged forest areas and newly forested ones did not compensate for losses incurred as a result of conversions of forest areas and finally the forest balance in this period amounted to -321 ha. Arable lands replaced forest areas (see Figs. 7 and 9a).

In the period from 1888 to 1940 forests in Poznań were characterised by insignificant changes. Only slight increase in the forest area took place, namely 23 ha in total. The period 1940-1960 was significant for the development of forest cover proportion of the city of Poznan. As much as 2135 ha of new forest areas were added. This was connected with the action of foresting agricultural lands and wastelands within the interwar period. In comparison to the first period the area of unchanged forest almost doubled within this period. Further, the amount of forest areas excluded from forest use decreased. All these components had an influence on the values of the forest balance to the level of +2649 ha (see Figs. 7 and $9 b$ ).

Between 1960 and 1979 the forest area increased 715 ha during this time. Within this period, the area of afforestation dropped to 1549 ha and the area of deforestation more than doubled from 419 ha to 834 ha. Areas which were not subject to change were considered to be a positive component of the balance. Their value amounted to 2249 ha. Forest balance for the period 1960-1979 amounted to +2959 ha and reached the highest value out of all comparative periods. The last comparative period, 1979-2004, brought small changes and minimum decrease in the forest area by 7 ha (see Figs. 7 and 9c).

To sum up, in the period 1830-2004 the balance of forest areas increased and its final value amounted to +2367 ha. Three components had an influence on this result:
- unchanged forest areas which have not changed over 170 years and occupy an area of 481 ha,

- newly forested areas which grew by 3075 ha within the analyzed period,

- deforested areas, the value of which amounted to 1431 ha as a result of the urban agglomeration development (Figs. 8 and 9d).

\section{Conclusions}

Forests constitute in Poznań a very significant form of land use. They are also a part of a wedgering system of urban greenery of Poznań. Forest areas prevail mostly in eastern, western and southern wedges.

Meeting the objectives set in the article allowed to draw the following conclusions:

- within the studied period i.e. 1830-2004 the area of afforestation amounted to 3075 ha. Forest area in Poznań changed from 2154 ha in 1830 by 1352 ha in 1888, to 3798 ha in 2004 (see Fig. 4). Afforestation was caused mostly by works connected with forest plantings of wastelands and post-agricultural lands during and shortly after World War II. Forest cover increased in the area of: Krzyżowniki, Psarskie, Strzeszyn, Golęcin, Junikowo, Dębina, Starołęka, Głuszyna, Piotrowo, Główna, Główieniec, Naramowice and Radojewo;

- 1431 ha of areas were deforested, and at present these areas are occupied by housing developments, and they constitute industrial and service areas of Umultowo, Piątkowo, Morasko, Franowo and partially Spławie;

- forest areas which did not change their use within the analyzed period amount only to 481 ha $(14.6 \%)$ of forest areas, mostly within the area of Kobylepole and Morasko. Thus the balance of forest areas for the period 18302004 amounts to +2367 ha;

- land use dynamics resulted in change in forest cover proportion of the city of Poznan from $8.2 \%$ in 1830 through $5.2 \%$ in 1888 to $14.5 \%$ in 2004. Four stages can be distinguished:

1. period 1830-1888 $\rightarrow$ decrease in forest areas by $37.21 \%$ (from 2154 ha to 1352 ha); 
2. period 1888-1940 $\rightarrow$ minimum increase in forest areas by $1.68 \%$ (from 1352 ha to 1375 ha);

3. periods $1940-1960$ and $1960-1979 \rightarrow$ the greatest increase in forest areas by $176.73 \%$ (in total for both periods - from 1375 ha to 3091 ha in the first one and from 3091 ha to 3805 ha in the second one);

4. period 1979-2004 $\rightarrow$ minimum decrease in forest areas by $0.19 \%$ (from 3805 ha to 3798 ha).

Thus in terms of the age structure of forest, forest stands of age class 3 and 4 prevail (41-80 years old), which corresponds to the greatest, in the history of Poznan, action of afforestation of wasteland and post-agricultural lands in the history of Poznan, in the $20^{\text {th }}$ century.

currently constant changes of forest areas located within administrative borders of the city of Poznan take place as a result of restoring previously lost lands by individual persons as well as public entities and transferring lands for the purpose of afforestation (e.g. total forest land was increasing from 4004 ha in 2004 to 4089 ha in 2008 according to Regional Data Bank 2009).

The knowledge of the history of the changes of forest areas has on important meaning for the environment of the city. The continuous forest is of greater environmental value. Even in the urban environment these forests play on important role to maintain biodiversity. They can also constitute on element of recreational system of a city. In the city of Poznań, habitat type of a forest as well as its species composition are favourable.

Forests constitute precious and most numerously represented component of all forms of nature protection in Poland (Walczak et al. 2001; Ochrona środowiska 2009). Their maintenance is important from the point of view of their significance for maintaining the continuity of green wedges which serve the function of ecological corridors in environment combing green areas in the city centre with the areas on the suburbs. Therefore, maintenance and increase of forest areas as the element of implementation of sustainable development principles should be one of the directions of spatial management of the city of Poznań.

\section{References}

Barbier E.B., Burgess J.C. \& Grainger A., 2010. The forest transition: Towards a more comprehensive theoretical framework. Land Use Policy, 27, 2, 98-107.

BŁASZYK H., 1974. Rozwój lesistości Wielkopolski (Forestation rate development in Wielkopolska region). Kronika Wielkopolski, 3, Urząd Wojewódzki w Poznaniu, Poznań.

Gemeindelexikon für die Provinz Posen, 1888. Königlichen Statistischen Bureau, Berlin.

Grey G.W., 1996. The urban forest: comprehensive management, John Willey \& Sons, New York.

Global Forest Resources Assessmment 2000. Main Report, 2001. FAO Forestry Paper, 140.

HŁADYŁowicz K.J., 1932. Zmiany krajobrazu i rozwój osadnictwa w Wielkopolsce od XIV do XIX wieku (Landscape changes and settlement development in Wielkopolska region from the $14^{\text {th }}$ to $19^{\text {th }}$ century), Badania Dziejów Spotecznych i Gospodarczych, Lwów.

KocIĘCKI S. \& ANDRZEJEWSKI R., (eds.), 1991. Mała Encyklopedia Leśna (Little Forest Encyclopaedia), 1991. Wydawnictwo PWN, Warszawa.

KozAK J., 2005. Zmiany powierzchni lasów w Karpatach Polskich na tle innych gór świata (Changes of forest cover in the Polish Carpathians in relation to other mountains of the world). Wyd. Uniwersytetu Jagiellońskiego, Kraków.

KureK R., (ed.), 1996. Środowisko naturalne miasta Poznania (Natural environment of the city of Poznań). Urząd Miejski w Poznaniu, Wydział Ochrony Środowiska, Poznań.

MATUSZYŃSKA I., 2001. Zmiany użytkowania terenu jako element transformacji środowiska przyrodniczego na obszarze wybranych zlewni Poznania $i$ jego strefy podmiejskiej (Land use changes as an element in the transformation of the urban environment in selected catchments of Poznan and its suburban area). Wydawnictwo Poznańskiego Towarzystwa Przyjaciół Nauk, Wydział Matematyczno-Przyrodniczy, Prace Komisji Geograficzno-Geologicznej, 30, Poznań.

MieRZWińsKI A., 1991. 100 stów o ekologii i ochronie środowiska. Wyd. Bellona, Warszawa.

Miller R.W. 2007. Urban Forestry: Planning and Managing Urban Greenspaces. Waveland Press, Long Grove, Ill.

Moll G.\& EBENRECK S., 1989. Shading our cities: a resource guide for urban and community forests. Island Press, Washington.

OвміŃski Z., 1978. Ekologia lasu (Ecology of forest). Wydawnictwo PWN, Warszawa.

OCHRONA ŚRODOWISKA 2009 (ENVIRONMENT 2009), 2009. Główny Urząd Statystyczny, Wydawnictwo GUS, Warszawa.

Oleksiejuk E. \& JANKOWSKA A. (ed.), 2007. Zieleń miejska. Naturalne bogactwo miasta. Lasy w miastach Unii Europejskiej. Zasady gospodarowania i ochrona (Urban greenery. Natural resources of the city. Forests in the cities of the EU. The priciples of management and protection). Wydawnictwo PZIiTS, Torun.

Plan Urządzenia Lasu Komunalnego Miasta Poznania na okres od 1 stycznia 2003 r. do 31 grudnia 2012 r.(Municipal Forest Arrangement Plan of the city of Poznań), 2002. Zarząd Zieleni Miejskiej w Poznaniu, Poznań.

Plan Urzadzenia Lasu Nadleśnictwa Babki na okres 1.01.2008 - 31.12.2017 (Forest Arrangement Plans of Forest Division Babki), 2008. Regionalna Dyrekcja Lasów Państwowych w Poznaniu, Poznań.

Plan Urzadzenia Lasu Nadleśnictwa Konstantynowo na okres 1.01.2008 - 31.12.2017 (Forest Arrangement Plans of Forest 
Division Konstantynowo), 2008. Regionalna Dyrekcja Lasów Państwowych w Poznaniu, Poznań.

Plan Urzadzenia Lasu Nadleśnictwa Łopuchówko na okres 1.01.2008 - 31.12.2017 (Forest Arrangement Plans of Forest Division Łopuchówko). 2008. Regionalna Dyrekcja Lasów Państwowych w Poznaniu, Poznań.

Regional Data Bank, 2009. www.stat.gov.pl

Rocznik statystyczny Poznania (Statistical Yearbook of Poznań), 2005. Urząd Statystyczny w Poznaniu, Poznań.
Ustawa $z$ dnia 28 września 1991 r. o lasach (Forest Act of $28^{\text {th }}$ September 1991). Dziennik Ustaw, 1991, nr 101, poz. 444 (Journal of Laws of 1991, No 101, Item 444).

Walczak M., RadZiejowski J., SmogorzeWSKa M., SienKieWicz J., Gacka-GrZesikiewicz E. \& Pisarski Z., 2001. Obszary chronione w Polsce (Protected areas of Poland). Wydawnictwo IOŚ, Warszawa. 